\title{
Idealisasi TVRI sebagai TV Publik: Studi "Critical Political Economy"
}

\author{
Lisa Adhrianti
}

\begin{abstract}
In the beginning, media was established as an integral part of public sphere. As the world changed, media turned to be commercialized as commodity by mass distribution operation. Media was also sold to advertisers which use media facilities to reach their customers. This turnover had moved media more and more far away from the ideal of public sphere. It amounted when contents of media were dominated by less educated and less morality program. In order to implement public broadcasting media, an effort to create public sphere was badly needed. One of such effort was transformation of TVRI status to Public Broadcasting Organization by UU No. 32/Th. 2002. But, in reality, the operationalization of TVRI as Public

$T V$ still face some obstacles. This paper examines several regulation barriers faced by TVRI that prevent an ideal public sphere.
\end{abstract}

Kata kunci: TV publik, Undang-Undang Penyiaran, "Critical Political Economy"

\section{Pendahuluan}

\subsection{Latar Belakang}

Televisi sebagai media komunikasi adalah alat komunikasi yang dalam perkembangannya menjadi kebutuhan primer bagi manusia, khususnya di era informasi saat ini. Kelebihannya sebagai media pandang-dengar (audiovisual) dan sifat aktualitasnya menjadikan televisi sebagai media favorit keluarga.

Industri televisi kemudian berkembang menjadi industri padat modal yang dikelola dengan dukungan teknologi canggih sebagai implikasi globalisasi industri media. Dalam perjalanannya, industri televisi di setiap negara memiliki karakter serta perkembangan yang khas pada setiap tahapannya. Uang yang ditanamkan untuk bisnis televisi jauh lebih mahal daripada modal untuk bisnis media cetak atau penyiaran radio. Tingkat persaingan antarstasiun televisi juga jauh lebih keras, baik dalam memperbutkan kue iklan, pemirsa, tayangan-tayangan impor atau lokal terbaik (Kurniati dalam Sudibyo, 2004:54).

Di Indonesia sendiri, pada awal perkembangannya hanya memiliki satu stasiun televisi nasional, yakni TVRI yang berperan sentral dalam setiap kegiatan komunikasi politik pemerintah. Latar sejarah ini membuat TVRI selaku lembaga penyiaran publik tidak bisa berfungsi optimal dan terjadilah monopoli informasi karena TVRI menjadi TV ideologis yang melulu mengagung-agungkan pemerintah, khususnya presiden dan keluarganya melalui peliputan seremonial para pejabat, terutama presiden yang memang bertujuan untuk 
melanggengkan kekuasaan rezim saat itu.

Dominasi TVRI berakhir pada 1988, ketika

RCTI(Rajawali Citra Televisi) lahir sebagai televisi swasta pertama di Indonesia, kemudian berturutturut disusul SCTV (Surya Citra Televisi), TPI (Televisi Pendidikan Indonesia), ANTEVE (Andalas Televisi), Indosiar (PT Indosiar Visual Mandiri), Metro TV (PT Media Televisi Indonesia), Lativi (PT Pasaraya Mediakarya), Global TV (PT. Global Informasi Bermutu), TV7 (PT Duta Visual Nusantara), Trans7, JakTV, dan SpaceToon.

Kehadiran industri televisi swasta di Indonesia muncul dalam konteks kebijkan top down lebih daripada kebutuhan daripada kebutuhan dari masyarakat atau publik. Wacana yang berkembang dari pertumbuhan industri televisi tersebut lebih mengarah ke kepentingan ekonomi politik elit penguasa, dan oleh karenanya kepentingan dan kebutuhan publik untuk membangun ruang diskusi publik sekaligus melakukan perkembangan peradabannya belum menjadi kebutuhan yang signifikan.

Televisi sendiri sudah dipahami sebagai alat kapitalis yang digunakan untuk melanggengkan dominasi kelas yang berkuasa. Beberapa faktor menjelaskan hal ini, antara lain, pertama pendirian televisi swasta, lebih banyak didorong oleh kepentingan ekonomi politik domestik internasional daripada inisiatif publik. Kedua, dengan sendirinya isi muatan dari televisi tersebut dapat dipastikan lebih memenuhi kepentingan ekonomi politik penggagas dan pemilik. Ketiga, industri televisi muncul tanpa dilandasi wacana publik dan tidak memiliki landasan hukum dan filosofi pendiriannya. Keempat, industri televisi swasta muncul dengan membangun segmensegmen khalayak melalui pemrograman acaranya, lebih untuk kepentingan ekonomis, yaitu iklan daripada kepentingan yang bersifat mendasar, yaitu pengembangan masyarakat atau publik, sehingga saat ini benar-benar telah terjadi apa yang dikhawatirkan oleh Habermas bahwa saat ini telah terjadi 'depolitisasi public sphere' akibat kapitalisme lanjut.

Public Sphere sekarang telah mengalami erosi di mana kehidupan mulai dikomodifikasikan, khususnya dalam media massa sebagai akibat dari perpindahan keterlibatan orang-orang dalam masyarakat sebagai warga negara dari negaranagara bangsa menuju pada keterlibatan mereka sebagai unit-unit konsumsi dalam dunia korporasi media massa. Media menjadi sulit tampil sebagai wadah bagi berkembangnya ranah publik (public sphere), di mana setiap warga negara bisa melibatkan diri dalam diskursus tentang masalah sosial dan untuk melakukan kontrol terhadap negara dan pasar (market), orang betul-betul bebas untuk berbicara, mempunyai akses sama untuk berbicara dan distribusi kekuasaan berlangsung secara simetris dalam media massa (ideal speech situation).

Di tengah dilema pertelevisian tersebut, pemerintah melalui Undang-Undang Penyiaran Nomor 32 Tahun 2002, membuat regulasi baru bagi lalu-lintas penyiaran di tanah air. Regulasi dan pengawasan adalah sebuah kemutlakan untuk media massa, peraturan, dan pengawasan, justru diperlukan untuk melidungi hak-hak publik karena efek mediasi yang luar biasa atas media tersebut. Regulasi bukan membatasi isi, melainkan menata sistem supaya ada keadilan. Demokrasi memberi kebebasan dan mekanisme pasar agar muncul yang terbaik. Namun, demokrasi juga menjunjung tinggi regulasi untuk menjamin terjadinya keadilan. Tanpa regulasi, keadilan akan mudah dimanipulasi oleh kelompok kekuatan tertentu yang mempunyai kekuasaan dan kapital (Winadono, 2006:113).

Menurut Feintuck (1998:51), dewasa ini regulasi penyiaran mengatur tiga hal, yakni struktur, tingkah laku, dan isi. Regulasi struktur (structural regulation) berisi pola-pola kepemilikan media oleh pasar, regulasi tingkah laku (behavioral regulation), dimaksudkan untuk mengatur tata laksana penggunaan properti dalam kaitannya dengan kompetitor, dan regulasi isi (content regulation) berisi bahasan material siaran yang boleh dan tidak untuk disiarkan. Dalam konteks diversitas politis dan kultural, regulasi penyiaran juga mesti berisi peraturan yang mencegah terjadinya monopoli atau penyimpangan kekuatan pasar, proteksi terhadap nilai-nilai pelayanan publik (public service values) dan pada 
titik tertentu berisi pula aplikasi sensor yang bersifat paternalistik (Mufid, 2007: 73).

Demi jalan bagi terwujudnya media penyiaran publik, pemerintah melalui regulasi tersebut sekaligus berupaya menampilkan indentitas baru TVRI sebagai televisi yang mampu mengakomodasi kebutuhan publik sebagai wadah ruang publik (public sphere) dengan mengubah status TVRI menjadi Lembaga Penyiaran Publik (LPP). Tujuannya agar TVRI dapat menjadi TV publik yang netral dan independen dalam segala hal.

Namun dalam penerapannya saat ini, masih terlihat ketimpangan antara regulasi dan konsepsi ideal dari public sphere mengenai lembaga penyiaran publik seperti TVRI. Beberapa pasal dianggap masih belum mencerminkan konsepsi ideal tersebut seperti pada pasal 14 ayat (1) dan (2) Undang-Undang Penyiaran Nomor 32 Tahun 2002 yang akan menjadi pembahasan dalam makalah ini.

\subsection{Tujuan}

Berdasarkan latar belakang dan permasalahan, maka tulisan ini berupaya mengkritisi UndangUndang Penyiaran Nomor 32 tahun 2002 tentang Lembaga Penyiaran Publik pada Pasal 14 ayat (1) dan (2) dalam hal ini TVRI sebagai upaya untuk membongkar ketimpangan antara regulasi tersebut dengan konsep ideal dari public sphere yang dikembangakan oleh Habermas berdasarkan pendekatan kritikal political ekonomi agar dapat menghasilkan suatu alternatif pemikiran bagi idealisasi TV publik.

\section{Kerangka Pemikiran}

\subsection{Perspektif Ekonomi Politik}

Pendekatan ekonomi politik merupakan sintesis yang mencoba memadukan ilmu politik dan ilmu ekonomi ke dalam suatu kerangka analisis yang lebih menyeluruh/komprehensif ( Sudarsono, 1989). Dengan kata lain, ekonomi politik merupakan suatu usaha untuk memadukan antara rasionalisme ekonomi dan kelayakan politik. Istilah ekonomipolitik sendiri tidak dimaksudkan untuk menunjuk suatu teori tertentu, melainkan untuk menggolongkan segala pendekatan yang dengan tegas meneliti hubungan timbal balik antara ekonomi dan politik (King, 1998:33-41).

Dalam perkembangannya, istilah ekonomipolitik selalu mengacu pada adanya interaksi antara aspek ekonomi dan aspek politik. Ditegaskan Mosco (1996:25) bahwa ekonomi politik komunikasi pada dasarnya merupakan "studi tentang hubungan-hubungan sosial, khususnya hubungan-hubungan kekuasaan yang secara bersama-sama membentuk atau memengaruhi produksi, distribusi, dan konsumsi sumber-sumber daya, termasuk di dalamnya sumber-sumber komunikasi (suart kabar, buku-buku, video, film, dan khalayak yang merupakan sumber utama komunikasi). Dengan bahasa yang lebih tajam Mosco mendefinisikan ekonomi-politik sebagai "the study of control and survival in social life", (Mosco, 1996:26).

Mosco juga mengemukakan, paling tidak ada tiga hal yang mendasar terkait dengan kajian ekonomi-politik. Pertama, ekonomi-politik merupakan bagian yang sangat penting dalam studi tentang perubahan sosial dan transformasi historis. Kedua, ekonomi-politik menaruh perhatian besar dalam mengkaji hubungan sosial secara menyeluruh termasuk di dalamnya mengkaji masalah-masalah ekonomi, politik, sosial dan kebudayaan. Ketiga, ekonomi-politik commited dengan filosofi moral. Artinya, kajian ekonomipolitik punya kepentingan dengan nilai-nilai sosial dan prinsip-prinsip moral (Boyd-Barret, 1995:186).

Golding dan Murdock (1991) menambah poin keempat, yaitu bahwa perhatian utama kajian ekonomi politik terkait dengan masalah "keseimbangan antara perusahaan kapitalis dan intervensi publik".

\section{2 "Critical Political Economy"}

Pendekatan ini merupakan pendekatan ekonomi politik yang lain dalam bidang komunikasi yang dikembangkan Golding dan Murdock dan dikenal dengan pendekatan ekonomi politik kritis (Critical Political Economy). Pendekatan ini berbeda dengan mahzab ekonomi mainstream karena sifatnya yang holistik, historis, lebih 
menekankan keseimbangan antara institusi kapitalis dan intervensi publik, serta yang terpenting adalah bahwa ekonomi politik kritis menjangkau isu-isu teknis tentang efisiensi dalam kaitannya dengan persoalan mendasar mengenai moral, khususnya menyangkut keadilan, persamaan, dan public good.

Ekonomi politik kritis bermula dari hubungan sosial dan permainan kekuasaan. Perhatian utama ekonomi politik kritis terletak pada bagaimana menciptakan dan memanfaatkan makna yang dibentuk pada masing-masing level oleh hubungan sosial yang terjalin secara sistematis dan terstruktur. Hubungan sosial bisa muncul dari hubungan yang terjadi antara pers dan editor atau antara wartawan dan nara sumbernya. Ekonomi politik kritis juga menaruh perhatian pada cara-cara dimana aktivitas komunikasi terbangun melalui distribusi material dan sumber-sumber simbolik yang timpang (Golding \& Murdock, 1991:18).

Untuk memberikan gambaran tentang fokus perhatian dan prioritas dari pendekatan ekonomi politik komunikasi, Golding, dan Murdock (1991:22) menyebutkan ada tiga bidang analisis. Pertama, fokus pada produksi karya seni budaya, di mana ekonomi politik komunikasi menjadi bagian yang penting untuk membatasi dampak dari produksi budaya terhadap banyaknya konsumsi budaya. Kedua, teks ekonomi-politik komunikasi menggambarkan cara-cara menghadirkan representasi produk media dikaitkan dengan realitas materi produksi dan konsumsi. Ketiga, konsumsi budaya ekonomi-politik menggambarkan hubungan antara materi dan ketimpangan budaya di mana ekonomi politik itu hadir. Kontribusi utama ekonomi-politik adalah menganalisis bagaimana dan dengan cara apa hubungan antara media dan negara mengakibatkan kesenjangan antara ekspresi dan gagasan dalam arena publik.

\subsection{Konsepsi "Public Sphere"}

\subsubsection{Konsep Ideal}

Dalam kajian public sphere, liberty of the press dapat dijadikan sebagai starting point untuk kritisme dan diskusi lebih mendalam tentang me- dia dan masyarakat, karena pada dasarnya public sphere dapat merefleksikan bahwa media massa memang benar menjadi a social institution yang mampu memfasilitasi pembentukan opini dengan menempatkan dirinya sebagai wadah independent untuk perdebatan public - di mana media tidak terkontrol oleh sensorship negara dan pasar (capital owner).

Konsep public sphere berasal dari hasil kerja Jurgen Habermas pada tahun 1962. Public sphere merupakan sebuah formasi pengertian 'publik', bukan sebagai prinsip yang abstrak, tetapi sebagai suatu penanaman praktek social secara budaya dan ini membicarakan analisis media secara historis.

Menurut Garnham, public sphere yaitu kebebasan yang ada pada gereja dan negara serta prinsip-prinsipnya. Pada abad ke 18, cofffee house dianggap sebagai 'public sphere' bagi kaum borjuis, suatu forum di mana surat kabar dan jurnal dibacakan dan didiskusikan secara bersama-sama (face to face). Ini dapat membantu dalam memfasilitasi hubungan antara kaum aristocrat dan para pengusaha. Karena pada dasarnya, media pertama (pada abad ke-18) merupakan bagian integral dari public sphere, tetapi ketika media dipasarkan melalui distribusi massa, di mana audiens media dijual kepada pengiklan, maka media menjadi jauh dari peran tersebut. Pada abad ke -20 , media mengutamakan berita-berita politik dalam public sphere borjuis, yang Habermas sebut corruption of commercialization pada media massa. Sejak periode Glasnot, pada tahun 1980-an, di mana runtuhnya Uni Soviet dan Komunisme di Eropa Timur, muncullah kebutuhan yang mendesak, di negara-negara Eropa untuk melakukan privatisasi media public dan komersialisasi yang lebih intensif atas media swasta, dengan tujuan meningkatkan public sphere. Ini memicu terjadinya perkembangan ekonomi kapitalis media yang luar biasa, tetapi akhirnya mengakibatkan penurunan public sphere, karena adanya, yang menurut Habrmas, yaitu commodification of media dan bahkan Elliot menyatakan telah terjadinya commercialization of society.

Pada tahun 1980-an, dengan kebangkitan kapitalisme dapat dengan cepat memfasilitasi 
pertumbuhan komupter dan alat komunikasi elektronik, sehingga mentransformasikan dan melemahnya pasar buruh, tetapi sebaliknya menaikkan informasi barang dan jasa (terciptanya budaya hedonistik dan memarjinalkan berita/isi politik) dan mengakibatkan juga lemahnya kontrol atas monopoli kapital atas mass market atau adanya the free operation of the market. (lihat tulisan Nicholas Garnham, The Media and The Public Sphere dan Approaches to The Media : A Reader, Boyd Barret:1995)

Dalam industri media, cara proteksi yang paling efektif adalah monopoli publik yang dilindungi oleh negara dan dioperasikan sesuai dengan prinsip public good. Ini menunjukkan harus adanya positive re-evaluation atas ekspansi pihak swasta yang bebas, sebab mulai terlihat secara nyata adanya manfaat bagi publik.

Habermas melihat masyarakat sebagai the bourgeuis moment of capitalism, karena masyarakat massa berkembang berdasarkan pada tingkat perilaku yang akseptabel, kesenangan (pleasure), dan kontrol, sebab orang berpartisipasi karena sebagai anggota.

Daniel Bell (1976\&1980) juga menyatakan bahwa masyarakat sedang terkena sihir (a sleight of hand). Adanya ledakan informasi dan komunikasi yang akhirnya menciptakan information-based society. Ini hanya sebuah sihir yang terletak pada teknologi baru yang menciptakan akses informasi dan membuka kesempatan baru two-way communication, tetapi sebenarnya ini bermasalah, yaitu pada level akses dan informasi serta komunikasi.

Media sangat mendukung konsep public sphere karena memberikan arena untuk perdebatan (diskusi) politik, sehingga diskusi tentang free press masih tetap berlangsung, agar dapat mensuplai informasi dan merefleksikan opini yang sebenarnya dan diharapkan dapat membantu perkembangan demikrasi. (Elliot, 1995)

Habermas sendiri menyatakan bahwa public sphere saat ini membutuhkan public body dari individu yang terorganisasi untuk menggantikan yang tak terorganisasi (defunct), karena public sphere hanya dapat direalisasikan ketika adanya reorganisasi rasional kekuatan politik dan sosial di bawah kontrol bersama dari organisasi rival yang tetap berkomitmen pada public sphere dalam struktur internal serta hubungannya dengan negara dan yang lainnya (Habermas, 1979:201).

Kekuatan konsep public sphere yaitu terkait dengan pengertian pelayanan publik yang bersifat universalisme, di mana lingkup struktur keputusan politik atau kekuasaan harus dapat dikontrol. Ini biasanya berada dalam batasan negara-negara bangsa (the nation-state) yang kemudian kewarganegaraan dari negara tersebut didefinisikan dalam terminologi hak dan kewajiban universal secara nasional - adanya hak berpartisipasi dalam pembuiatan keputusan.

Struktur media sebagai sentral atas pemerintahan demokratis dan universalisme, maka kontrol media nasional tertuju pada kekuasaan ekonomi pada level internasional atau perlu adanya pengawas (controller) untuk modal multinasional (melalui pasar di mana arus modal bersifat sangat bebas dan tidak dibatasi oleh peraturan dan batasan negara) dalam rangka melindungi negara bangsa dan warganya, tetapi modal tersebut juga memiliki kebaikan, yaitu dapat mengembangkan jaringan komunikasi privat (swasta). (Barret: 1995)

Jadi, untuk sekarang ini, kita akan menghadapi tantangan pengembangan public sphere bukan hanya pada level nasional, tetapi juga pada level internasional - adanya kejahatan institusi dalam bentuk 'politicization'.

Konsep public sphere pada awalnya merujuk pada gagasan yang dikembangkan oleh Habermas terhadap penggambaran bourgeois public sphere di Inggris pada abad ke-17. Public sphere dapat dipahami sebagai sebuah arena bagi kaum borjuis saat itu untuk berdiskusi secara bebas dan rasional tanpa tekanan negara dan pasar. Semua peserta diskusi ditempatkan secara sejajar untuk secara bebas mengemukakan opini mereka untuk melakukan pengawasan terhadap kebijakan negara. Konsepsi public sphere pada intinya menunjuk pada suatu kawasan atau ruang yang netral di mana public diberikan kesamaan akses dan berpartisipasi dalam wacana public dalam kedudukan yang sama pula (Curran, dalam Hidayat 
2002:15)

Dalam kebebasan seperti sekarang ini, di mana orang sudah diberikan bahkan dijamin haknya oleh undang-undang untuk menyampaikan pendapatnya secara bebas tentu secara tidak langsung telah memberi kontribusi bagi terwujudnya public sphere. Hanya saja, untuk mengorganisasi, memobilisasi dan mensosialisasi opini tersebut menjadi sebuah opini kolektif dan memiliki kekuatan real untuk memonitor sekaligus mengkritisi kebijakan negara membutuhkan mediator yang juga dapat dijamin independensinya dari himpitan pasar dan negara. Mediator tersebut secara strategis akan menempatkan media, baik cetak maupun elektronik menjadi pilihan bagi proses pembentukan opini kolektif tersebut. Televisi, misalnya, diharapkan mampu menempatkan diri sebagai salah satu elemen utama bagi tegaknya public sphere dalam proses penyelenggaraan wacana publik. Namun, di tengah arus neoliberalisme yang mengarah pada pemusatan modal dan kepemilikan media, berbagai kalangan mulai pesimis terhadap potensi dan prospek media massa komersial sebagai public sphere (Hidayat, 2002:16).

\subsubsection{Kritik terhadap "Public Sphere"}

Perkembangan selanjutnya, teori Habermas tersebut mendapat kritik karena adanya kenyataan bahwa sejumlah media pada saat tertentu masih menjadi media dialog bagi publik tentang isu-isu yang menarik perhatian publik antarorang-orang yang berpengetahuan, tertarik, mampu untuk berbicara atas nama kepentingan sosial yang lebih luas. Bahkan, ada media yang berpotensi menyebarkan pandangan dan pengaruh politik tertentu.

Di masa modern seperti sekarang ini, media telah mampu menciptakan publi mereka sendiri, juga menciptakan forum diskusi bagi publiknya sendiri. Dalam kondisi demikian, cita-cita media sebagai katalisator penyebarluasan informasi dan fasilitator bagi perdebatan publik dalam kerangka membangun public sphere paling tidak dapat merepresntasikan pilihan publik yang beragam. Namun, tentu saja kondisi tersebut masih jauh dari harapan membangun public sphere paling yang ideal bila media hanya bertindak secara sepihak melibatkan publik tanpa memberikan akses yang luas bagi publik untuk menentukan sendiri pilihan materi pemberitaannya. Keterlibatan publik ini bisa dilihat dari mulai keikutsertaan publik dalam merencanakan kebijakan, membuat, melaksanakan sekaligus memantau program yang disajikan media.

Untuk melindungi kepentingan publik oleh media, menurut Murdock (lihat dalam Oliver BoydBarret, 1995) dalam public sphere memuat tiga prinsip, yaitu:

(1) Kebutuhan masyarakat demokratis (warga negara) untuk memiliki akses terhadap informasi, sarana (device), dan analisis yang akan membuat mereka mampu mengetahui dan berusaha memeroleh hak-hak pribadi mereka.

(2) Adanya akses informasi yang luas dan kebebasan berdiskusi (berdebat) dalam wilayah yang terkait pada pilihan politik publik.

(3) Fasilitas bagi masyarakat untuk mengenali diri mereka sendiri dan aspirasinya yang terepresentasi di media, serta dapat memberikan kontribusi atas pengembangan masyarakat (Boyd-Barret, Conceptualizing of The Public Sphere, 1995).

\subsection{Lembaga Penyiaran Publik}

Effendi Gazali dan Victor Menayang (2002:41) memberikan batasan definisi penyiaran publik sebagai berikut:

Lembaga penyiaran publik adalah lembaga penyiaran yang mempunyai visi untuk memperbaiki kualitas kehidupan publik, kualitas kehidupan suatu bangsa, dan juga kualitas hubungan antarbangsa pada umumnya, serta mempunyai misi untuk menjadi forum diskusi, artikulasi, dan pelayanan kebutuhan publik. Lembaga penyiaran ini memberikan pengakuan secara signifikan terhadap peran suvervisi dan evaluasi oleh publik dalam posisinya sebagai kalayak dan partisipan aktif. Karena itu, lembaga penyiaran publik bukanlah lembaga penyiaran pemerintah, serta bukan pula lembaga penyiaran yang semata-mata mendasarkan dirinya pada 
hukum pasar.

Oleh karena sifat-sifatnya pada definisi di atas, terdapat empat implikasi utama bagi hadirnya lembaga penyiaran publik:

(1) Akses publik

Lembaga penyiaran publik bersedia mendirikan stasiun atau bersiaran di daerah-daerah yang umumnya tidak ingin didatangi atau dijadikan wilayah siaran dari lembaga penyiaran komersial, karena di daerah tersebut dianggap tidak ada potensi keuntungan ekonomis.

(2) Dana publik

Lembaga penyiaran publik terutama beroperasi dengan dukungan dana publik. Misalnya melalui dana publik yang dikelola oleh pemerintah misal APBN/APBD. Dana publik juga bisa berasal dari aneka ragam kegiatan pencarian dana oleh lembaga penyiaran publik bersama publiknya (fund rising) termasuk menggunakan kesempatan-kesempatan di dalam program atau penyiarannya, seperti program iklan atau sponsor; asalkan kriteria iklan dan sponsor, etika penempatannya, atau secara makro mengenai pemasukan dan pengeluaran, telah mendapat semacam kegiatan untuk mendapatkan supervisi dari publik; lalu ditindaklanjuti dengan akuntabilitas publik.

(3) Akuntabilitas publik

Ada dua poin utama, pertama lembaga penyiaran publik harus mempertanggungjawabkan segala programnya dengan ukuran moral dan tata nilai publik yang dilayaninya (moral accountability). Kedua diwajibkan membuat laporan kebutuhan maupun proses penggunaan uang kepada publik (financial Accountability).

(4) Keterlibatan publik

Lembaga penyiaran publik diharapkan bekerja sama seluas-luasnya, mengundang serta menyambut keterlibatan publik, khususnya melalui sebuah lembaga supervisi penyiaran publik pada tingkat-tingkat yang relevan dengan keberadaan lembaga tersebut (misal nasional atau daerah).

Dalam UU No. 32 pasal 14 ayat (1) lembaga penyiran publik didefinisikan sebagai "lembaga penyiaran yang berbentuk badan hukum yang didirikan oleh negara, bersifat independen, netral, tidak komersial, dan berfungsi memberikan layanan untuk kepentingan masyarakat".

Menurut Harmens Tahir (2002:154, 159), televisi publik mengacu kepada sisitem benefolent, dalam arti merupakan suatu organisasi nirlaba yang dibentuk oleh publik, dimiliki oleh publik dan juga dikontrol public. Ketentuan siaran TV publik bervariasi dari satu negara ke negara lain, misalnya Hermens mengambil Resolusi Eropa 1996:

(1) TV publik mendukung terwujudnya masyrakat informasi, sebagai agen pemersatu pluralisme berbagai kelompok dalam masyarakat untuk pembentukan opini publik.

(2) TV publik menyiarakan program siaran yang bermutu untuk segala lapisan masyarakat.

(3) TV publik mampu menciptakan standar kualitas program sebagai tuntutan bagi khalayak.

(4) TV publik mampu melayani kepentingan kelompok penduduk minoritas.

(5) TV publik menyiarkan informasi yang independen dan objektif, sehingga menjadi referensi bagi publik dalam mengantisipasi perubahan yang sangat cepat.

(6) TV publik berperan penting untuk mendorong pelaksanaan debat publik dalam rangka mewujudkan demokrasi.

(7) TV publik menjamin bahwa masyarakat memeroleh akses layanan yang menjadi kegemaran sebagain besar masyarakat.

Menyikapi munculnya Lembaga Penyiaran Publik, Victor Menayang (dalan Gazali, 2002:iv) mengingatkan agar tidak terjebak pilihan yang semu antara dua model "the falacy of the two model choice”: sistem yang dirancang untuk memaksimalkan keuntungan dan sistem yang terang-terangan berisi propaganda pemerintah.

Memang banyak contoh Lembaga Penyiaran Publik di dunia yang memiliki kekhasan masingmasing. Di antaranya, BBC (Inggris), PBS (AS), ABC (Australia) dan NHK (Jepang). Namun, umumnya satu pola yang mesti ada adalah 
keterlibatan publik secara optimal. Menurut Effendi Ghazali (Kompas, 5 April 2003 dalam Heryanto, 2003:38), Lembaga Penyiaran Publik hakekatnya adalah diakuinya supervisi dan evaluasi publik pada level yang signifikan. Karena adanya keterlibatan publik itu, maka umumnya stasiun publik tidak dapat bermanuver mencari keuntungan sebebas stasiun komersial. Namun juga tidak berarti stasiun publik tidak boleh untung.

Terdapat dua istilah yang mirip berkaitan dengan diskusi tentang penyiaran publik, yaitu penyiaran publik (public broadcasting) dan penyiaran pelayanan publik (public service broadcasting).

Penyiaran publik (public broadcasting) dan penyiaran pelayanan publik (public service broadcasting) dapat dibedakan berdasarkan institusi dan fungsinya. Penyiaran publik lebih dikaitkan pada institusinya sebagai lembaga penyiaran yang di dalamnya terkandung masalah hukum, kepemilikan, dan status lembaga. Sedangkan penyiaran pelayanan publik akan dikaitkan dengan fungsi yang dijalankan oleh lembaga penyiaran. Perbedaan tersebut muncul karena pada praktiknya sulit mewujudkan lembaga penyiaran publik sesuai dengan definisi, semangat, visi, dan tujuannya. Akibatnya, banyak lembaga penyiaran yang mengklaim dirinya sebagai penyiaran publik, tetapi secara substansial justru mengomersilkan kepentingan publik. Terhadap lembaga penyiaran yang menampilkan beberapa agenda publik, tetapi tidak melibatkan publik dapat ditempatkan sebagai lembaga penyiaran pelayanan publik, belum masuk dalam definisi lembaga penyiaran publik. Sebab, untuk menjadi sebuah lembaga penyiaran publik bukan hanya saja melayani publik, tetapi lebih jauh juga melibatkan publik dalam kepemilikan, penyusunan program dan evaluasi.

Secara dikotomis, pembedaan tersebut dapat dilihat dari definisi yang diberikan Leonard (1999) dalam Efendy dkk (2000) :

"....Public broadcasting is broadcasting that is publicly owned. That is, owned by the state or the government or a public corporation. As apposed to broadcasting that is privately owned. Public service broadcasting on the other hand is program- ming transmitted in the interent of the public. It might be educational, or cultural, or informational programming. It is programming that provides some sort of service to the public, to help people in their daily lives."

Bila kita merujuk pada pengertian dan definisi yang diajukan Leonard tersebut dan kemudian menariknya pada Undang-Undang Penyiaran Nomor 32 Tahun 2002, maka akan ditemukan banyak persoalan yang menjadi perdebatan, terutama pada otoritas siapa yang berhak mendirikan lembaga penyiaran publik sebagaimana yang disebutkan dalam pasal 14 ayat (1) dan (2).

\section{Pembahasan}

Televisi Republik Indonesia (TVRI) lahir dan beroperasi tepat pada tanggal 17 Agustus 1962. Dengan pemancar berkekuatan 100 watt, siaran yang pertama dilakukan terhadap peringatan hari ulang tahun ke 17 Proklamasi Republik Indonesia dari halaman Istana Merdeka Jakarta. Inilah momentum di mana Indonesia mengukuhkan diri sebagai negara Asia ke empat yang memiliki media penyiaran televisi setelah Jepang, Philipina, dan Thailand.

Pada awalnya, TVRI adalah "proyek khusus" untuk menyukseskan penyelenggaraan Asian Games IV di Jakarta. TVRI adalah bagian dari proyek "mercusuar" pemerintahan Soekarno. Sebuah proyek yang menempatakan gengsi bangsa di mata dunia luar sebagai prioritas utama, melebihi kebutuhan-kebutuhan riil bangsa yang lain.

Dalam latar belakang seperti ini, TVRI kemudian berperan sentral dalam proses komunikasi politik pemerintah. Dari sekadar medium untuk mendokumentasikan sejarah, TVRI pada akhirnya lebih berperan sebagai perangkat ideologis rezim berkuasa. Dalam praktiknya, TVRI lebih banyak diperlukan sebagai alat propaganda pemerintah. Fakta sejarah inilah yang menjadi kendala serius pada saat ingin mentransformasikan TVRI menjadi "lembaga penyiaran publik", karena sejak awal TVRI memang tidak diorientasikan sebagai media untuk memenuhi kepentingankepentingan publik. TVRI adalah medium propa- 
ganda politik ke luar dan dalam negeri, serta medium konsolidasi kekuasaan dan monopoli informasi oleh pemegang kekuasaan (Sudibyo, 2004:280).

Namun pada akhirnya melalui UUNo. 32 tahun 2002 tentang penyiaran yang resmi berlaku pada tanggal 28 Desember 2002, TVRI berubah statusnya dari Perusahaan Jawatan (Perjan, sejak Orde Reformasi) menjadi Lembaga Penyiaran Publik (LPP).

Urgensi media penyiaran publik adalah untuk menjunjung nilai-nilai yang banyak ditinggalkan oleh media komersial, seperti independensi, solidaritas, keanekaragaman (opini dan akses), objektivitas, dan kualitas informasi. Ranah publik diharapkan dapat menjadi zona bebas dan netral yang di dalamnya berlangsung dinamika kehidupan yang bersih dari kekuasaan dan pasar (Senjaja, 2001:3 dalam Mufid, 2007:80). Ranah publik yang secara relatif memiliki otonomi dan independensi, yang di dalamnya berlangsung kegiatan kultural dalam berbagai aspek kehidupan fungsional.

Civil society sebagai format baru kehidupan publik diharapkan dapat menjadi visi bersama penyelenggaraan media massa, terutama televisi. Membangun civil society pada dasarnya adalah membalik arus utama yang tadinya 'dari kekuasaan negara dan pasar ke warga', menjadi 'dari warga kekekuasaan negara dan pasar' (Mufid, 2007:81).

Dari visi yang semacam itu dapat dibayangkan misi yang perlu dijalankan, sesuai dengan fungsi media penyiaran dalam ranah publik. Dalam hal ini, fungsi dan posisi pemerintah dan Komisi Penyiaran Indonesia (KPI) sebagai badan regulasi penyiaran juga harus netral tanpa ada kepentingan politis bagi kekuasaan tertentu dalam menjalankan misi mewujudkan visi media penyiaran TV publik.

Kata publik, ketika membicarakan lembaga penyiaran publik, umumnya akan dilekatkan dalam konteks warga negara (citizen) dengan hak-hak yang melekat pada dirinya. Menjadi warga negara dengan mendapatkan hak-haknya adalah konsekuensi logis secara hukum dari kontrak sosial bersama yang melahirkan negara. Jika penyiaran publik dikatkan dengan ide tentang warga negara, maka secara logis ia harus dipisahkan dari kekuasaan negara dan pada saat yang bersamaan ia juga tidak bisa diperdagangkan (Gazali dkk, 2002:27-28).

Terlepas dari perdebatan tersebut, televisi sebagai media yang dalam siarannya menggunakan fasilitas publik, tidak dapat semena-mena melalaikan kepentingann publik. Bahkan idealnya, televisi dapat menjadi promotor untuk menstimulus penciptaan ruang publik (public sphere) yang sehat. Bila televisi merealisasikan gagasan public sphere yang ideal, sekurang-kurangnya konsep public sphere itu relevan untuk ditempatkan sebagai sebuah konsepsi normatif atau ideal speech situation yang dapat dijadikan acuan kriteria sejauh mana masyarakat telah mampu memenuhi salah satu dimensi kehidupan bernegara yang demokratis.

Lembaga Penyiaran Publik menjadi bahasan penting untuk masuk dalam permasalahan TVRI saat ini. Hal ini berkaitan dengan legitimasi formal dalam UU No.32 tahun 2002 tentang penyiaran yang menyebutkan TVRI sebagai lembaga penyiaran publik (pasal 14 ayat 1 dan 2).

Pada bagian IV, pasal 14 ayat (1) disebutkan: Bahwa lembaga penyiaran public sebagaimana dimaksud pada pasal 13 ayat (2) huruf a adalah lembaga penyiaran yang berbentuk badan hukum yang didirikan oleh Negara, bersifat independent, netral, tidak komersial, dan berfungsi memberikan layanan untuk kepentingan masyarakat.

Secara tegas, undang-undang tersebut menyatakan bahwa lembaga penyiaran publik didirikan oleh negara. Kendati dijamin bersifat independen, netral, dan tidak komersial, namun siapa yang dapat menjamin hal tersebut dapat terlaksana, mengingat yang mendirikan lembaga penyiaran publik adalah negara? Ditunjang oleh sejarah yang menunjukkan bahwa TVRI juga identik dengan problem kemandirian karena watak paternalistik yang menunjukkan fakta bahwa TVRI didirikan oleh Presiden Soekarno untuk tujuantujuan yang juga sangat kental dengan subjektivitas Soekarno. Bukan sebagaimana lazimnya penyiaran publik yang lahir atas inisiatifinisiatif dari bawah, dan berangkat dari kebutuhankebutuhan berbasis publik atau komunitas, 
sebagaimana yang termaktub dalam konsep ideal public sphere. Dalam kajian public sphere, independensi dan netralitas dapat dijadikan acuan, karena pada dasarnya public sphere dapat merefleksikan bahwa media massa memang benar menjadi a social institution yang mampu memfasilitasi pembentukan opini dengan menempatkan dirinya sebagai wadah independen untuk perdebatan publik - di mana media tidak terkontrol oleh sensorship negara dan pasar (capital owner).

Dalam faktanya, perubahan-perubahan penting TVRI seluruhnya merupakan produk dari proses politik yang bersifat top down. TVRI sepanjang sejarahnya sangat tergantung pada garis kebijakan pemegang kekuasaan, sehingga TVRI tidak pernah mendapat kemandirian dan independensi karena harus selalu menyesuaikan dengan orientasi dan kebutuhan praktis pemerintah.

Kita bisa melihat pada contoh lembaga penyiaran pubik, seperti ABC di Australia, BBC di Inggris, dan NHK di Jepang yang memang lahir dengan diktum "melayani seluruh masyarakat melalui program-program yang utuh, mendidik, informatif, tepat, dan tanggap secara budaya, menghibur, dan bermutu tinggi”. Seperti dikatakan Ang (1991 dalam Sudibyo, 2004:289), sistem penyiaran publik memiliki ciri adanya kesadaran tentang pentingnya tanggung jawab moral terhadap publik yang tentunya berbeda dengan prinsip penyiaran swasta yang cenderung melihat publik sebagai konsumen yang harus digarap dengan prinsip-prinsip pasar.

Dalam konteks inilah, rumusan yang diajukan Leonard tentang lembaga penyiaran publik yang memberikan kesempatan pada lembaga lain selain negara dapat mendirikan lembaga penyiaran publik menjadi relevan. Memang, untuk menuju ke arah pembentukan lembaga penyiaran publik yang benar-benar independent tanpa campur tangan dari negara dan pasar, sulit dicapai, bahkan terkesan utopis. Namun, sebagai acuan normatif yang ideal, semangat lembaga penyiaran publik secara substantif harus terus dipelihara.

Lebih lanjut, undang-undang tersebut telah menempatkan RRI dan TVRI sebagai Lembaga Penyiaran Publik. Pasal 14 ayat 2, Undang-undang Penyiaran Nomor 32 tahun 2002 menyebutkan:

Lembaga penyiaran public sebagaimana dimaksud pada ayat (1) terdiri atas Radio Republik Indonesia dan Televisi Republik Indonesia yang stasiun pusat penyiarannya berada di Ibu Kota Negara Republik Indonesia.

Dengan demikian, tertutuplah sudah pintu hukum bagi pengadaan penyiaran publik yang benar-benar muncul dan diprakarsai serta dikelola oleh publik sendiri secara independen, terutama pada daerah lain di luar ibu kota negara Republik Indonesia. Padahal, Indonesia bukan hanya Jakarta saja dan yang menjadi dasar dari keberadaaan sebuah lembaga penyiaran publik adalah basis kultural dari keberadaan media penyiaran publik sebagai institusi publik ditentukan oleh nilai bersama (shared value), yang bisa jadi berasal dari berbagai publik di luar ibu kota.

Pada awalnya, TVRI memulai siaran dengan tujuan pelayanan masyarakat. Namun TVRI bukan penyiaran publik yang lahir dari bawah. Karakteristik kepemimpinan Soekarno kemudian menjadi acuan Presiden Soeharto di masa Orde Baru, dengan paham pemerintahan yang sentaralistik, hegemonic dan otoritarian. Akibatnya, berbagai lembaga Negara dan lembaga masyarakat dikendalikan oleh kekuatan tunggal untuk tujuan dan imajinasi kekuasaan semata (Winardono, 2006:5)

TVRI yang tidak disiapkan secara sempurna, dalam prosesnya kemudian digunakan oleh Soeharto bukan sebagai media massa, melainkan lembaga penyiaran yang sangat berkepentingan untuk melanggengkan kekuasaaan yang hegemonik. TVRI menjadi media pemerintah, bukan media massa. Dan karena itu, tidak mengabdi pada kepentingan masyarakat, melainkan mengabdi pada penguasa.

Sekalipun dalam hal manajemen pengelolaan mengalami perubahan dan perkembangan, TVRI seolah tetap memosisikan masyarakat sebagai objek yang hanya diminta duduk tenang, melihat dan mendengarkan saja. Tidak ada proses interaksi, sehingga masyarakat tidak mendapatkan 
akses untuk terlibat.

Pemberitaan TVRI sudah sedemikan identik dengan ritual-ritual pembangunan khas Orde Baru, tanpa terkecuali hingga lahirnya televisi-televisi swasta pada tahun 1990-an. Program "Berita Nasional" menjadi wahana utama representasi simbolik dari ideologi pembangunan Orde Baru dan bagaimana media televisi dilibatkan.

Namun, penyiaran publik sebagai wacana dan diskursus harus tetap digelorakan untuk membangun kerangka ideal yang bersifat normatif bagi institusi penyiaran. Karena itu, pendapat beberapa kalangan akademisi yang terlibat dalam diskursus penyiaran publik tetap relevan untuk direnungkan seperti yang dikemukakan oleh Effendi Gazali dan Victor Menayang (2002:41) di bab sebelumnya tentang batasan definisi penyiaran publik yang mengandung implikasi bahwa lembaga penyiaran publik memberikan akses yang sama pada publik, beroperasi dengan dukungan dana publik, memilki akuntabilitas publik dan melibatkan publik seluas-luasnya.

\section{Kesimpulan dan Saran}

Berdasarkan uraian pada bab-bab sebelumnya, maka dapat disimpulkan berdasarkan pemikiran critical political economy bahwa status TVRI saat ini sebagai lembaga penyiaran publik yang idealnya merupakan lembaga yang independen, netral, tidak komersial dan berfungsi memberikan layanan untuk masyarakat serta seharusnya mampu melibatkan publik di luar konteks ibu kota negara dalam pendiriannya belum seutuhnya terpenuhi, hal ini dapat terlihat pada uraian UU Penyiaran Nomor 32 tahun 2002 dalam pasal 14 ayat (1) dan (2).

Masih terdapat kesenjangan antara regulasi penyiaran tentang lembaga penyiaran publik dengan konsep ideal dari public sphere dan TV publik itu sendiri karena terbukti memang TVRI saat ini belum sepenuhnya netral/terlepas dari dominasi aparatus (pemerintah) serta independen melalui kebebasan pers yang benar-benar fungsional bagi demokratisasi, yakni kebebasan pers yang mendorong kebebasan publik untuk mendapatkan keragaman isi dan kemasan, serta untuk menikmati produk-produk yang berkualitas dan tidak membahayakan konsumen dalam pasar bebas informasi, serta kebebasan pers yang memfasilitasi publik untuk memperoleh akses memadai ke forum-forum pembentukan pendapat umum. TVRI saat ini juga masih "terikat" pada sistem sentralistik (terpusat) yang dikendalikan oleh kekuatan tunggal dari pemerintah pusat yang berkedudukan di ibu kota Jakarta.

Sebagai saran, dapat dikemukakan bahwa untuk mencapai idealisasi TVRI sebagai TV publik sejatinya mampu mendekati konsep ideal dari $p u b$ lic sphere yang menuntut adanya ideal speech situation dalam media melalui liberty of the press demi pencapaian media sebagai institusi sosial yang terlepas dari campur tangan negara dan pasar dengan konsisten mengimplementasikan ciri, fungsi, dan prinsip dari lembaga penyiaran publik itu sendiri yang mengacu kepada sistem benefolent, dalam arti merupakan suatu organisasi nirlaba yang dibentuk oleh publik, dimiliki oleh publik dan juga dikontrol publik dengan memberikan akses yang sama pada publik, beroperasi dengan dukungan dana publik, memilki akuntabilitas publik dan melibatkan publik seluasluasnya.

TVRI diharapkan dapat menjadi medium bagi pewarisan nilai-nilai yang bermanfaat dari satu generasi ke generasi lainnya atau dari satu kelompok ke kelompok lainnya dengan lebih terbuka dan akomodatif terhadap respons-respons dari publik, sehingga mampu mengeleminasi problem-problem struktural, profesionalisme, dan etika dalam realitas pertelevisian saat ini.

\section{Daftar Pustaka}

Boyd-Barret, Oliver dan Cgris Newbold. 1995. Approach to Media A Reader. J.W. London: Arrowsmith.

Dokumen UU Penyiaran No. 32 tahun 2002.

Tahir, Harmens. 2002. TVRI sebagai TV Publik Sumbagan Pemikiran terhadap Keberadaan 
TVRI, dalam 40 tahun TVRI Dari Pembebasan Menuju Pencerahan. Jakarta: FSP-TVRI.

Habermas. 1989. Institution of The Public Sphere.

1993. Jurgen, The Structural Transformation of The Public Sphere An Inquiry into a Category of Bourgeois Society, Translated by Thomas Burger. Cambridge Massachusetts: MIT Press.

Garnham. 1990. The Media and The Public Sphere.

Gazali, Effendi. 2000. Penyiaran Alternatif tapi Mutlak. Jakarta: Jurusan Ilmu Komunikasi Fisip UI.

dkk. 2003. Konstruksi Sosial Industri Penyiaran. Jakarta: Jurusan Ilmu Komunikasi Fisip UI.
Golding, Peter dan Graham Murdock. 1991. Cultural Communication and Political Economy, dalam James Curran dan Michael Gurevith (Eds) Mass Media and Society. Edward Arnold, p. 15-32. London.

Mosco, L.J. 2002. The Political Economy of Communication: Rethinking and Renewal. London: Sage Publication.

Mufid, Muhammad. 2007. Komunikasi dan Regulasi Penyiaran. Jakarta: Kencana Prenada Media \& UIN Press.

Mulyana, Deddy. 2001. "Membangun TV Publik." Jurnal Mediator Volume 2 Nomor 2. Bandung: Fakultas Ilmu Komunikasi Unisba.

Sudibyo, Agus. 2003. Ekonomi Politik Media Penyiaran. Yogyakarta: LKiS 